\title{
Effect of Auditor Ethics, Knowledge and Dysfunctional Behavior Audit Office of the Quality of Public Accountants in Makassar
}

\author{
Eva Marin Sambo, Hj. Yusuf Marwah, Andi Fadillah A Baso \\ STIEM Bongaya Makassar, Indonesia \\ coralie_ms@yahoo.co.id
}

\begin{abstract}
Cases of violation of the Public Accountants Professional Standards at Drs. Mitrawinata and colleagues, due to unfavorable auditor ethics where Drs. Peter Partner Winatadari as Public Accountant (AP) violated the Public Accountants Professional Standards (SPAP) relating to the audit that the general audit assignment restrictions on financial statements Muzatek Jaya. Associated with good audit quality, there are several things that affect them auditor ethics, knowledge and dysfunctional behavior. This study aims to determine the effect of auditor ethics, knowledge and dysfunctional behavior on audit quality either simultaneously or partially on public accounting firm in Makassar. The sampling technique using saturated sampling technique, in order to obtain a sample of 37 respondents. Methods of data analysis using multiple linear regression techniques, test $\mathrm{F}$ and test $\mathrm{t}$. These results indicate that the auditor ethics, knowledge and dysfunctional behavior simultaneously significant positive effect on audit quality in the public accounting firm in Makassar. Partially ethics of auditors and knowledge of significant positive effect on audit quality, but not for the dysfunctional behavior that significant negative effect on audit quality. The level of contribution influence auditor ethics, knowledge and dysfunctional behavior on audit quality is high. This is caused by some respondents to variable auditor ethics, knowledge and quality of the audit is still no answer neutral and do not agree, while the dysfunctional behavior variables still exist some respondents who answered disagree and strongly disagree.
\end{abstract}

Keywords: Ethics Auditor, Knowledge, Dysfunctional Behavior and Quality Audit

\section{Introduction}

Audit is a process to reduce the lack of information contained harmony between managers and shareholders. So companies should be more critical in choosing the public accounting firm (KAP) to audit the company's financial statements. Besides being used by the results of the audit firm also used by outside parties such as prospective investors, investors, creditors, Bapepam and other relevant parties to assess the company and taking strategic decisions related to the company. In this case public accountant serves as a third-party management company that connects with interested parties outside the company duty to give confidence and provide an opinion on the fairness of the financial statements as a basis for making a decision that the financial statements presented by management to be believed. Public accounting profession is a profession of public trust. Of the public accounting profession, the public expects that assessment independent and impartial to the information presented by the company management in the financial statements. Public accounting profession is responsible for raising the level of reliability of the financial statements of the company, so that the public obtain reliable financial information as a basis for decision making. As with other professions, accountants also have codes of conduct which are used as guidelines or restrictions when an Accountant to perform its role. Sufficient understanding of the accounting code of ethics, personal accountant will be professional, competent and efficient. Without a sufficient understanding of the code of conduct, an accountant will be impressed not elegant, even would eliminate the essential value of the highest of the profession. To support his professionalism as a public accountant, the auditor in carrying out audit tasks should be guided by auditing standards established by the Indonesian Institute of Accountants (IAI), the common standards, standards of field work and reporting standards. But in addition to standard audit, public accountant must also comply with a code of ethics governing the conduct of public accountants in running practice the profession with fellow members and the general public. The code of ethics regulates the responsibility, competence and professional prudence, confidentiality, professional behavior, even knowledge as well as technical standards for an auditor in performing their duties. 


\section{Theoretical Overview}

The auditor is a person who has a certain qualification in performing audits of financial statements and activities of a company or organization. According to Arens et al. (2008) auditor is a person who expressed an opinion on naturalness in all material respect, the financial position and results of operations in accordance with the flow coat accounting principles generally accepted in Indonesia. According to Mulyadi (2002), the terms of the public accounting profession, the auditor is the examination objective of financial statements of a company or other organization with the aim to determine whether the financial statements present fairly, in all material respects, the financial position and results of operations of the company or organization. Science (from the Latin "scientia", which means "knowledge" is an activity that systematically build and organize knowledge in the form of explanations and predictions about the universe. In Indonesian dictionary of science is defined as the knowledge of a field arranged in applying according to certain methods, which can be used to explain certain symptoms in the field of knowledge. (Sumarma, 2007:56). According Soekidjo (2005) measurements can be done with the knowledge of the interview or questionnaire that asks about the content of the material to be measured from the research subjects or respondents. The factors are expected to influence the development of knowledge accountants and examiners according Sularso and Na'im (1999) include: audit experience, discussions with colleagues about the audit, supervision and review of work by the accountant inspector supervisor, training programs, the follow-up audit planning, and the use of audit guidelines. According Donelly et al. (2005: 266) dysfunctional behaviors include action report audit time with the total time is shorter than the actual time (underreporting of audit time), change the procedures established in the audit field (replacing and altering original audit procedures), completing audit steps too early without completing the whole procedure. Time budget pressure is defined as the obstacles that occur in the audit engagement because of limited resources in the form of time allocated to carry out the entire auditing (Dezoort and Lord, 1997). Auditor dysfunctional behavior described as the behavior of auditors in the audit process that directly or indirectly leads to reduced audit quality. One cause of this behavior is the time budget pressure. Competition and the reduction of client trust in the profession led to cost pressures for this profession (Sujana and Sawarjuwono, 2006). The pressure generated by a tight time budget was consistently associated with dysfunctional behavior. Time budget pressure is a condition that indicates the auditor is required to perform efficiency on time budget that has been prepared or there is discussion of a very tight budget and rigid (Sososutikno, 2003). The factors causing the supporting components behave dysfunctional an auditor can come from internal factors (personal characteristics of auditors) and external factors (situational factors when conducting the audit). Malone and Robert (1996) in Nurul (2014) argue individual behavior is a reflection of the personalitanya whereas situational factors that occur will encourage someone to make a decision. Therefore, audit quality is difficult to measure. This is supported by a statement Mardiasmo (2009: 127) that the indicators of quality of performance and service standards is an indicator that is difficult to measure because it involves subjective considerations. In other words, the size of the quality of the audit is still being debated. Research conducted by Tarigan et al. (2013), which examines the Influence of Competence, Ethics and Audit Fee on the Quality Audit. Response in this study is Drs in Central Jakarta. Where the results of research for Auditor Ethics variable is declared to have a significant positive effect on audit quality either simultaneously or partially. Research conducted Tarigan et al. (2013) using the KAP in Central Jakarta, while the research use of KAP in Makassar. Research conducted by Wandita et al. (2014) the effect of the test on knowledge, experience and Accountability Audit on the Quality Audit. Having a positive result between the dependent variable to the independent variables. Research conducted by Purwanda and Shiddieqhy (2013) test on The Influence of Auditor Personality Characteristics and Dysfunctional Behavior to Audit Quality. Based on the analysis performed, Personal Characteristics Auditor has a significant positive effect on audit quality. Purwanda and Shiddieqhy (2013) using the KAP in Bandung in 2013, while researchers used a KAP in Makassar 2015. Research conducted by Purnamasari and Hernawati (2013), which examines the effect of auditor ethics, experience, knowledge, and dysfunctional behavior on audit quality response in this study are Drs in Central Jakarta. Research by Purnamasari and Hernawati (2013) using the KAP in Central Jakarta, while the research use of KAP in Makassar

\section{Methodology}

In this research using a quantitative research approach. According to Sugiyono (2013:35-36), quantitative research is used to examine the population or specific segments, data collection using research instruments, 
analysis of quantitative data in order to test the hypothesis that has been set. Population and sample in this research is the auditor who worker on audit firm (KAP) in Makassar which amount 37 respondents. Population is generalization region consisting of the objects/subjects that have a certain quantity and characteristics defined by the researchers to learn and then drawn conclusions (Sugiyono, 2013:148). According to Sekaran (2006:123), sample is a part of the population. The sample consisted members of the population, while according to Sularso (2003:67), sample is some members or selected part of the population. The sampling technique used in this research using nonprobability sampling (census sample) technique when all members of the population used as a sample (Sugiyono, 2013:156), so that the number of sample in this research is 37 respondent. The analysis method used in this research is multiple linear analysis method by the equation :

$\begin{array}{ll}\mathbf{Y}=\mathbf{a}+\mathbf{B}_{1} \mathbf{X}_{\mathbf{1}}+\mathbf{B}_{2} \mathbf{X}_{\mathbf{2}}+\mathbf{B}_{3} \mathbf{X}_{\mathbf{3}}+\mathbf{e} \\ \text { Where : } & =\text { Quality Audit } \\ \mathrm{Y} & =\text { Constants } \\ \mathrm{a} & =\text { Coefficients of multiple linear analysis } \\ \mathrm{b}_{1} \mathrm{~b}_{2} & =\text { Ethics Auditor } \\ \mathrm{X}^{1} & =\text { Knowledge } \\ \mathrm{X}^{2} & =\text { Dysfunctional Behavior } \\ \mathrm{X}^{3} & \end{array}$

\section{Result}

The analysis method used in this research is multiple linear analysis method. In the regression model, the value of the constants that are listed at 0.247 can be interpreted if the independent variable in the model assumed to be zero, the average variable outside the model will continue to improve the quality of audits by 0.247 units. B1 regression coefficient value of 0.682 in this study can be interpreted that the auditor ethics variable (X1) significant positive effect on the quality auditor (Y). This shows that when the ethics of auditors increased by one unit, the quality audit will also be increased by 0.682 units. B2 regression coefficient value of 0.333 in this study can be interpreted that the knowledge variable (X2) significant positive effect on audit quality (Y). This shows that when knowledge has increased by one unit, the quality audit will also be increased by 0.333 units. B3 regression coefficient value of 0.052 in this study can be interpreted that the dysfunctional behavior variable (X3) no significant effect on audit quality (Y). This shows that the higher the dysfunctional behavior that audit quality would be decreased by 0.052 units. In the simultaneous test (F test) result that the auditor ethics, knowledge and dysfunctional behavior significant positive effect on audit quality simultaneously. This is evidenced by the value of Faritmetic 31.252 which is greater than the value of 3.28 and significant Ftable seen of significance $(0.000)$ is smaller than the significance level that would otherwise require is 0.05 . The positive influence suggests that the better ethics, knowledge and dysfunctional behavior that are owned by an auditor, the audit quality will increase. Good ethics can be seen when the auditor is able to account for the audited report, respecting the public trust, lack of intimidation and partiality to anyone and is able to maintain the privacy / confidentiality on the audited statements. While good knowledge can be realized if the auditor has formal education and have experience with training-advanced training on a regular basis. While the increase is due to dysfunctional behavior or can be seen that in auditing often superficial auditors conduct a review of the documents the client and reduce the audit work of the audit program.

Increased dysfunctional behavior often does not affect the quality of the audit because the auditor has good ethics and knowledge in accordance with their competence. With more and better ethics, knowledge and dysfunctional behavior that are owned by an auditor, the audit quality will increase. Where the audit is a good quality when the auditor is able to detect errors client's financial statements, in conducting an audit in accordance with SPAP and cautious in carrying out its duties. Significant effect indicates that the auditor ethics, knowledge and dysfunctional behavior has a role in an enterprise especially those in the public accounting firm to provide services so that reports generated are of good quality. The coefficient of determination in this study amounted to 0.716 or $71.6 \%$, which means the value is high. In other words that the quality of the audit could be explained by variables auditor ethics, knowledge and dysfunctional behavior $71.6 \%$. This is due to the persistence of the respondents who answered the neutral and do not agree on a variable auditor ethics, knowledge and audit quality. As for variable dysfunctional behavior of respondents 
tend to answer agree and strongly agree. The variable ethics of auditors, there are two statements are: Statement of the seventh that the auditor must always weigh the problems of every effect there during the audit process, Statement of the eighth that the auditor should consider the state of a person / group of people or an organizational unit not justify actions that violate the provisions or the legislation in force. On the variable knowledge there are six of the seven statements contained neutral answer and disagree.

The first statement is to produce good quality audit the auditor requires knowledge gained from the level of formal education. The second statement that the auditor does not have to have a background in education S1 (Bachelor of Accountancy Economics) in producing good quality audits. The fourth statement is the level of education will shape the personality and knowledge development for an auditor. The fifth statement that auditors must follow in order to improve the quality of professional training of the sixth statement that the auditor must attend workshops and conferences or symposia to enhance the knowledge and skills. The seventh statement that continuous training can add to our knowledge in the field of accounting. While the variable dysfunctional behavior ten statements are answers to agree and strongly agree. The first statement is often auditor reports the audit period that is shorter than the actual time in the execution of audit engagements. The second statement is executing audit assignments outside of working hours (personal time) and did not report the audit time can degrade the quality of the audit. The third statement is the need to divert time audits that are used for the implementation of audit tasks on the client. The fourth statement that if the auditor implement or ignore one or several audit procedures specified in the audit program. The fifth statement that an audit failure occurs when the auditor documenting audit procedures are not complete as required but must be able to provide an opinion on the financial statements. The sixth statement that the auditor is not required to extend the scope of testing when detected postal or dubious accounts. The seventh statement that auditors often give less attention to the validity and accuracy of client documents. The eighth statement that if the auditor to test only in some sample items from the sample item specified, means it will be able to reduce audit quality. Ninth statement is as specified in the audit program, the auditor needs to reduce the audit work of the tenth held statement that the auditor should not carry out further investigations on the suitability of the accounting treatment applied to the client with generally accepted accounting principles. The variable quality of the audit there were six of the seven statements contained neutral answer and disagree.

The first statement is the quality of audits related to whether or not the auditor is able to find a material misstatement. The second statement that faults can be detected if the auditor has the expertise and precision in the client's financial statements is audited. The third statement that the auditor can audit performed quality if they meet the provisions or auditing standards. The fourth statement that if the auditor SPAP then apply the resulting audit quality will be good. The sixth statement that the auditor should always try to be careful in making decisions during an audit. The seventh revelation that the precautionary principle is an attitude to fulfill professional responsibilities with competence and diligence to produce good quality audit. The results are consistent with research Purnamasari and Hernawati (2013) with the result that the variable Auditor Ethics, Knowledge and Dysfunctional Behavior has a positive and significant impact on audit quality variables. In the second hypothesis (H2), where the results of multiple linear regression of this study is a significant positive in the amount of 0.682 , or in other words the second hypothesis $\mathrm{H} 2$ is accepted. These results reinforced with partial test ( $\mathrm{t}$ test). This is evidenced by the value of $\mathrm{t}$ arithmetic 6.263 greater than the value of 2034 and a significant $t$-table seen of significance $(0.000)$ is smaller than the significance level that would otherwise require is 0.05 . The positive influence suggests that the influence of ethics of auditors is in line with the quality audit or in other words, if an auditor has good ethics that can be seen when the auditor is able to account for reports to be audited, honorary the public trust, lack of intimidation and partiality to anyone and is able to maintain privacy / confidentiality on the audited reports it will affect both the quality of audits produced that is capable of detecting errors the client's financial statements, in conducting an audit in accordance with SPAP and cautious in carrying out its duties. Significant effect suggests that ethical auditor has an important role in improving audit quality. This means that when viewed from the standpoint of the public accounting profession, an auditor must have high ethical awareness at the time to do its job, namely the financial statements. So the quality of audits produced in accordance with the reality of the financial condition of the company audited. 
Based on the results of respondents to variable ethical auditors who have been described previously supported the definition disclosed by Adanan (2011:60) that the auditor has done its job in a professional manner if an auditor has a commitment to implement the code of ethics of public accountants. If that commitment is maintained, the violation can be avoided, and a Public Accountant can also improve the quality of the audit by Adanan (2011:60). Results of this study are also consistent with previous studies conducted by Tarigan et al. (2013), which conducts research on the influence of competence, ethics of auditors and audit fees to audit quality with the result that the auditor ethics significant positive effect on audit quality. In the third hypothesis (H3), where the results of multiple linear regression of this study is a significant positive in the amount of 0.333 , or in other words the third hypothesis $\mathrm{H} 3$ is accepted. These results reinforced with partial test ( $\mathrm{t}$ test). This is evidenced by the value of $\mathrm{t}$ arithmetic 2,096 greater than the value of 2034 and a significant $t$ table seen of significance (0.044) is smaller than the significance level that would otherwise require is 0.05 . The positive influence suggests that the influence of knowledge in line with the quality audit or, in other words if the auditor has formal education and have experience with training-advanced training on a regular basis it will affect both the quality of audits produced that is capable of detecting errors client's financial statements, in doing audit compliance with the SPAP and cautious in carrying out its duties. Significant effect suggests that knowledge plays an important role in improving audit quality. This means that, when viewed from the standpoint of the public accounting profession knowledge is an important element that must be owned by an auditor for audit work and produce good quality. Based on the results of respondents to the knowledge variable that has been previously described results of this study support the definition disclosed Wandita et al. (2014) that the high and low levels of education is the condition of one's own technique through practice and learning for years. Or have high levels of education and skills both as an auditor will produce good audit quality.

The results are consistent with previous studies conducted by Wandita et al. (2014), which conducts research on the influence of knowledge, experience and accountability of the audit work on the quality of the audit with the result that knowledge of significant positive effect on audit quality. Finally the fourth hypothesis (H4), where the same treatment as the previous hypothesis that multiple linear regression and partial test $(\mathrm{t}$ test) showed that dysfunctional behavior significant negative effect on audit quality. Position visible from the regression coefficient of 0.052 and dysfunctional behavior evidenced by the value of $t$ aromatic .264 smaller than the value of 2034 and a significant $t$-table seen of significance $(0.264)$ is greater than the significance level that would otherwise require is 0.05 . Negative influence shows that the more often the auditor performs actions or dysfunctional behavior such as audit reporting period shorter than the actual time, ignoring the audit procedure and a superficial review of the documents, the client will adversely affect the quality of audits produced. Poor audit quality can be seen when the auditor is not able to detect misstatements on a client's financial statements, the audit did not perform in accordance with the SPAP and not be careful in carrying out their duties. Based on the results of respondents to variable dysfunctional behavior previously described the results of this study support the definition expressed by Donelly et al. (2005) that dysfunctional behavior is associated with a professional attitude and ethics owned by an auditor. In this case if the auditor can get the job done in a professional manner, the quality of the audit would be assured because the quality is the main output of professionalism. The results are consistent with previous studies conducted by Purwanda and Shiddieqhy (2013), which conducts research on the influence of personality characteristic and dysfunctional auditor to audit quality behavior with the result that the dysfunctional behavior significant negative effect on audit quality. The acceptance of this last hypothesis, meanings the fourth hypothesis in this study is all accepted. The results support previous research conducted by Purnamasari and Hernawati (2013) with the results of simultaneous auditor ethics, knowledge and dysfunctional behavior has a positive and significant effect on audit quality. But for the dysfunctional behavior is not partially where all variables auditor ethics and knowledge has been proven (H0) and variable dysfunctional behavior (Ha accepted).

\section{Conclusion}

Ethics auditor, knowledge and dysfunctional behavior simultaneously significant positive effect on audit quality in the public accounting firm in the city of Makassar, which means the better ethics, knowledge and dysfunctional behavior that is owned by an auditor, the audit quality will increase. Ethics auditor significant positive effect on audit quality, the public accounting firm in Makassar. Knowledge significant positive effect 
on audit quality in the public accounting firm in Makassar. Dysfunctional behavior significant negative effect on audit quality in the public accounting firm in Makassar.

Suggestions: It is recommended to further develop knowledge in particular areas of auditing accounting are closely related to the ethics of auditors, knowledge and dysfunctional behavior and the quality of the audit. Further research is recommended to measure the quality of audit not only the variables auditor ethics, knowledge and dysfunctional behavior alone. But add the variables that affect the quality of the audit. In addition to adding a variable, it is advisable also to develop indicators of each variable and expands the object of study in order to better results and significant.

\section{Reference}

Adanan, S. (2011). Pengaruh Multidimensi Komitmen Profesional Terhadap Perilaku Audit Disfungsional. Jurnal Akuntansi \& Auditing, 8(1).

Alvin, A., Arens, R. J. \& Beasley, M. S. (2008). Auditing dan jasa Assurance, edisi keduabelas, jilid 1. Jakarta salemba empat

Angga F. (2012). Pengertian Auditor. Melalui http://capungtempur.blogspot.com (tanggal akses 29 Januari 2015).

DeZoort, F. T. \& Lord, A. T. (1997). A Review and Synthesis of Pressure Effects Research in Accounting. Journal of Accounting Literature, 16, 28-58.

Donelly, D. P., Quirin, J. J. \& O Bryan, D. (2005). Locus of Control and Dysfunctional Audit Behavior. Journal of Business \& Economics Research, 3(10).

Mardiasmo. (2009). Akuntansi Sektor Publik. Penerbit : CV. Andi Offset, Yogyakarta.

Mulyadi. (2002). Auditing. Buku 2. Edisi Ke Enam. Salemba Empat, Jakarta.

Nurul. (2014). Pengaruh Karakter Individual (Locus of Control), Tekanan Anggaran Waktu dan Moralitas Auditor Terhadap Perilaku Audit Disfungsional. Artikel Academia-Edu, pp : 2-3. Melalui http://www.academia.edu (tanggal akses 29 Januari 2015).

Purnamasari, D. \& Hernawati, E. (2013). Pengaruh Etika Auditor, Pengalaman, Pengetahuan dan Perilaku Disfunsional Terhadap Kualitas Audit. Jurnal NeO-Bis, 7(2).

Purwanda, E. \& Shiddieqhy, M. A. (2013). Pengaruh Karakteristik Personal Auditor dan Perilaku Disfungsional Terhadap Kualitas Audit. ISSN 1693-4482.

Sekaran, U. (2006). Research Methods for Business. Jakarta: Salemba Empat.

Soekidjo, N. (2005). Edisi III Metodologi Penelitian Kesehatan. PT Rineka Cipta. Jakarta.

Sososutikno, C. (2003). Hubungan Tekanan Anggaran Waktu dengan Perilaku Disfungsional serta Pengaruhnya terhadap Kualitas Audit. Simposium National Akuntansi, 3, 1116-1124.

Sugiyono. (2013). Method Penelitian Manajemen. Alfabeta, Bandung.

Sujana, E. \& Sawarjuwono, T. (2006). Perilaku Disfungsional Auditor: Perilaku yang Tidak Mungkin Dihentikan. Jurnal Bisnis dan Akuntansi, 8, 247-259.

Sularso, S. \& Na'im, A. (1999). Analisis Pengaruh Pengalaman Akuntan pada Pengetahuan dan Penggunaan Intuisi dalam Mendeteksi Kekeliruan. Jurnal Riset Akuntansi Indonesia, 2(1).

Sularso, S. (2003). Metode Penelitian Akuntansi: Sebuah Pendekatan Replikasi. Yogyakarta: BPFE-Yogyakarta. Sumarna, C. (2007). Filsafat Ilmu dan Perkembangannya di Indonesia. Bumi Aksara. Jakarta.

Sunyoto, D. (2011). Metode apenelitian Ekonomi, Alat statistik \& Analisis output Komputer. CAPS, Yogyakarta. Tarigan, M. U., Primsa, B. \& Susanti, K. (2013). Pengaruh Kompetensi, Etika, Fee Audit Terhadap Kualitas Audit. Jurnal Akuntansi, 13(1), 803-832

Wandita, N. L. P. T. A., Yuniarta, G. A. \& Darmawan, N. A. S. (2014). Pengaruh Pengetahuan, Pengalaman Kerja Audit dan Akuntabilitas Terhadap Kualitas Hasil Kerja Auditor Internal. Jurnal Akuntansi, 2(1). 